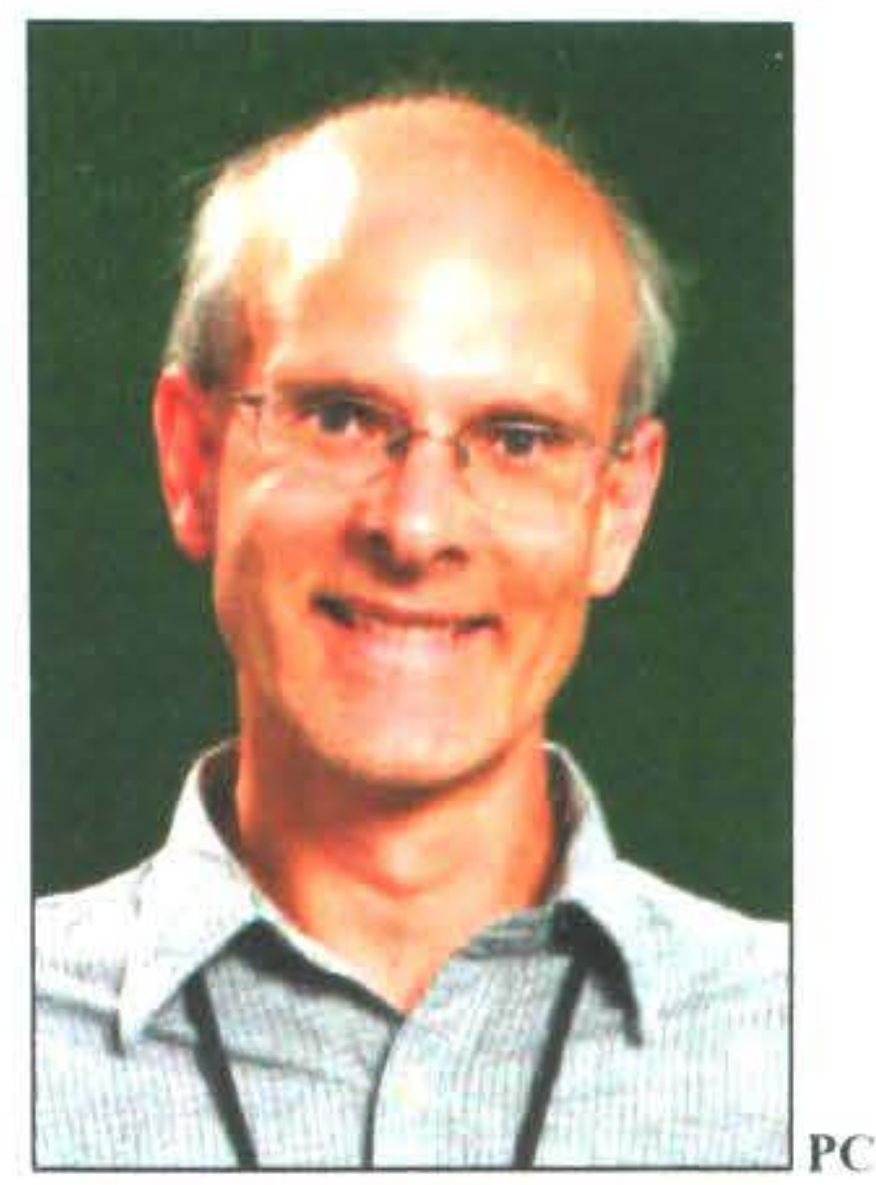

\title{
THE ORIGIN, FAMILY STRUCTURE AND LABOUR SUPPLY OF OVERSEAS BORN NURSES
}

\author{
Juthika Badkar \\ Institute of Policy Studies, Victoria \\ University of Wellington \\ Paul Callister \\ Institute of Policy Studies, Victoria \\ University of Wellington \\ Robert Didham \\ Statistics New Zealand
}

\begin{abstract}
Although a third of murses in New Zealand are born overseas, little is known about their composition. Among OECD countries, the reliance on overseas trained health professionals is currently strong and growing. Globally, as the population ages, and fertility rates decline, the demand for health professionals, particularly doctors and nurses is projected to increase over the next 20 years. It is estimated that in the OECD countries, 11 percent of employed murses and 18 percent of employed doctors were foreign born, however there are significant differences between the foreign-born and foreign-trained health professionals (OECD 2007).
\end{abstract}

The purpose of this paper is to gain an understanding of the origin of overseas-born nurses, their labour market outcomes and their family structures. In the OECD countries, the main countries of origin of foreign-born doctors and murses are India and the Philippines respectively. In New Zealand nurses from Great Britain form the largest supply of migrant murses followed by the Philippines. Overall, murses were more likely to migrate as part of a family unit compared to other occupational groups like doctors, however differences were observed by nationality.

The proportion of international mursing students has also grown. from 1percent (of total enrolments) in 1995 to 7 percent in 2006. The proportion of registered murses who were born in New Zealand has also changed and decreased from 82 percent in 1991 to 72 percent in 2006. These differences are more evident when examined by age groups.

Our study illustrates that severe staff and skill shortage within the health systems of developed countries such as New Zealand has led to the rise in migration of murses, leading to significant changes in the proportion of nurses who were born in New Zealand and overseas. The shift from a primarily New Zealand born to an increasingly diverse nursing workforce raises some challenges and opportunities when delivering services to a diverse range of clients..

\section{Introduction}

In New Zealand, as in all industrialised countries, demand for health services has been increasing and this demand is predicted to continue growing (Bach 2003; Cox and Hope 2006). The increase in demand for health services creates a growing need for health professionals, including nurses. Studies demonstrate that the health workforce in New Zealand, and for that matter the overall workforce, cannot be considered without taking into account migration. The health studies show that New Zealand has the highest proportion of migrant doctors in the OECD and one of the highest for nurses (Aiken et al 2004: Zurn and Dumont 2008). Data from the OECD shows that foreign-born nurses made up $29 \%$ of the New Zealand nursing workforce with foreigntrained nurses forming $24 \%$ of this workforce in 2005 06. The OECD data also suggests that New Zealand doctors have the second highest expatriation rates in the OECD and that this outward flow is also high for New Zealand nurses (23\%) (Zurn and Dumont 2008). While the OECD demonstrate that New Zealand has fewer doctors relative to the population than most OECD countries, their data suggest that New Zealand has a higher proportion of nurses relative to the population than the OECD average (Zurn and Dumont 2008)

The international migration of nurses is just one part of the reason that over the last 20 years the gender balance 
of international migration flows has changed considerably. As well as gender selective demand for foreign labour in many countries, economic and social development with subsequent changes in gender relations in countries of origin and countries of destination has also led to an increase in female migration. Although the marriage markets remain one driver of female migration as well as couples choosing to migrate, an increasing number of women migrate independently for employment purposes (Carling 2005). Income though remittances also play an important part in migration with reference to women, which has led developing countries like the Philippines to train nurses with the intention of 'exporting' them (Bach 2003; Aiken et al 2004).

Female migration is evident in both low and high skills jobs. In terms of low paid caring work, it is mainly women who fill these jobs and internationally sources of such workers include countries such as the Philippines and Thailand (Badkar et al 2006).

Skilled women have also tended to go into 'traditional' female jobs in welfare and social professions such as education, health and social work. This is noticeable in New Zealand with a considerable increase of migrant women classified as 'Professionals' in New Zealand (Badkar et al 2006).' However, within areas such as health increasingly women have not only moved strongly into non-traditional employment areas such as medical doctors, but have been migrating to fill these positions (Callister et al 2008).

In terms of gender and occupation, nursing remains to be the most female dominated sector, with 90 percent or more of the nursing workforce being comprised of women (Buchan and Calman 2004). Among OECD countries, the reliance on overseas trained health professionals is currently strong and growing. It is estimated that overall in the OECD countries, 11 percent of employed nurses and 18 percent of employed doctors were foreign born. However it is important to note that there are significant differences between the foreign-born and foreign-trained health professionals (OECD 2007). For example in Australia, 30 percent of domestic students enrolled in medicine were born overseas (Birrell and Dobson 2005). It is also important to remember that an exchange of nurses and doctors occurs between OECD countries. For example the majority of foreign trained nurses in New Zealand are from the United Kingdom.

In the OECD countries, the main countries of origin of foreign-born doctors and nurses are India and the Philippines respectively. Among the OECD countries, the United States of America attracts half of foreign-born doctors and nurses followed by Europe (40 percent), Australia and Canada (OECD 2007),

Globally, nurses from the Philippines remain the main source for the supply of nurses to OECD countries, and in terms of absolute numbers, the majority are drawn to the USA. However, there are large variations in the proportion of foreign-born nurses. Switzerland, for example, has the highest proportion of foreign-born nurses (29 percent) followed by Luxembourg (26 percent) and Australia (25 percent), while countries such as Mexico ( 0.2 percent), Poland ( 0.4 percent) and Finland ( 0.8 percent) have the lowest proportion of foreign-born nurses (OECD 2007; Zurn and Dumont 2008). ${ }^{2}$ Australia for example, has a growing proportion of nurses from non-English speaking backgrounds. Between $1982 / 3$ to $1993 / 4$ the main source country of foreign born nurses were from UK/Ireland (48\%) followed by Asia (25\%) and New Zealand/Oceania (12\%) (Hawthorne 2001).

As already noted, in New Zealand, 2006 census data shows that almost one-third ( 28 percent) of nurses were born overseas - one of the highest proportions in the OECD countries after Switzerland (OECD 2007).

Despite this high proportion of overseas born nurses in New Zealand, little is known about their composition and characteristics. The purpose of this study is two-fold. Firstly it aims to understand the characteristics of migrant nurses that enter New Zealand through the Skilled/Business stream and temporary work category; and secondly to examine the changes in the trends of nurses born in New Zealand and overseas over the last 15 years. This includes understanding the changing nature of the origin of overseas born nurses, their labour market outcomes and their family structures.

Like many other migrant destination countries, New Zealand has a government administered immigration programme. Briefly these include the New Zealand Residence Programme through which potential migrants can enter New Zealand via the Skilled/Business, Family Sponsored and the International/Humanitarian stream. Migrants can also come to New Zealand through various temporary categories as visitors, students and temporary workers. $^{3}$

In $2006 / 07$, of the 46,964 people were approved for residence, 28,140 were approved through the Skilled/Business Stream, 14,705 through the Family Sponsored Stream and 4,119 through the International/Humanitarian Stream. Although the UK was the largest source country of Skilled/Business migrants, followed by China, South Africa and the Philippines Skilled/Business approval numbers have decreased from these countries over the last 12 months, but have substantially increased from the Philippines making it the fourth largest source country in 2006/07 (Merwood 2008). ${ }^{4}$

The number of work permits issued to people has also increased substantially in recent year such that in $2006 / 07,115,457$ individuals were issued work permits. ${ }^{5}$ Of these, 16 percent were issued to people from the UK, followed by 13 percent from China. Other main source 
countries include Malaysia and the Philippines that have had significant increases over the last financial year ( 83 percent and 68 percent respectively) (Merwood 2008).

\section{Research questions}

Most studies in New Zealand look at the overall employment and labour market outcomes of immigrants (Winkelmann \& Winkelmann 1998; Boyd 2003; Badkar 2006). However research examining labour market outcomes of immigrants in specific occupational groups is scarce. Australian academic, Professor Lesleyanne Hawthorne has conducted an extensive amount of research on immigrants in specific occupational groups in Australia and Canada, including the migrant nursing workforce (Hawthorne 1994; 1996; 2001; 2002; 2006; 2007).

Therefore this study uses immigration and census data to answer the following questions:

1. What are the main source countries of migrant nurses, and do they migrate independently or with their families?

2. Over the last 15 years (1991 to 2006), how has the mix of nurses employed in New Zealand changed in terms of their age structures and whether they were born in New Zealand or overseas?

\section{Methodology}

We begin the analysis with a discussion of the migration flows into New Zealand. This is based on data is collected through the Department of Labour's Application Management System (AMS). This database contains information on whether the applicant was a principal or secondary applicant, their sex, age, and for the principal applicant information is collected on their occupation and region (in New Zealand) at the time of their application. These data allow us to determine whether the principal applicant was wishing to migrate alone or with a partner. In the analysis of flows, we consider both temporary (workers) and permanent migration (the skilled business stream).

We then analyse census data. We use data from the 1991 . 1996, 2001 and 2006 censuses. Census data are snapshot in each period but as such show broad trends over time. The census population reported is the usually resident population. Given the small number of male nurses, in most of the census data we only consider female nurses.

With AMS data, we study trends in nurse migration from the top 5 sending countries, namely, Great Britain, South Africa. China, India and the Philippines. ${ }^{6}$

With census data we examine trends in the number of nurses employed by ten yearly age groups and whether they were born in New Zealand or overseas. Further analysis dissecting the overseas born population further, based on duration of residence in New Zealand and nationality groups will be completed in the New Year, and published as an Institute of Policy Studies (IPS) working paper.

Finally, we draw on Ministry of Education data to show the number of foreign nursing students training in New Zealand.

\section{Results}

As background to both the migration data and the census analysis, the number of nurses working in New Zealand has been increasing over time. In 1991 and 1996 there were 28,041 and 28,014 nurses respectively. This increased to 30,843 in 2001 and 34,989 by 2006 .

\section{$\underline{\text { Immigration (AMS) data }}$}

\section{Skilled Business stream analysis}

Figure 1: Top 5 source countries of registered nurses entering New Zealand through the Skilled/Business stream as principal applicants (female only), 2003/04 $-2007 / 08$

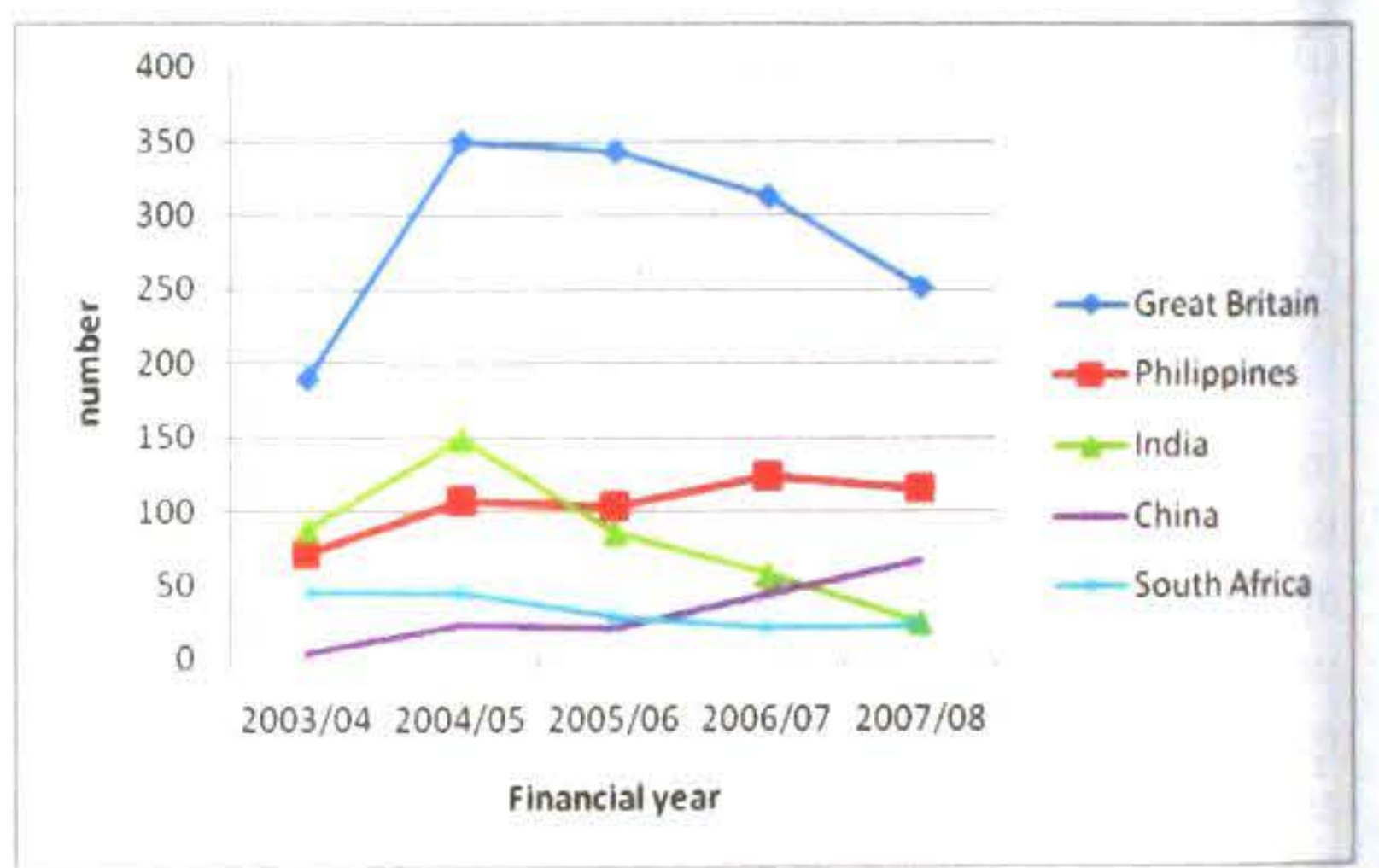

There has been an increase in the number of registered nurses entering New Zealand through the Skilled/Business stream. The number of female registered nurses has increased from 281 in 2003/04 to 445 in $2007 / 08$, while the number of male registered nurses has doubled from 34 in 2003/04 to 76 in 2007/08.

Figure 1 shows the top 5 source countries of registered nurses in New Zealand, who came to New Zealand through the Skilled/Business stream as principal applicants. Although the numbers of migrant nurses from Great Britain have declined since 2004/05, they still remain the largest source country of migrant nurses with close to 251 nurses entering New Zealand as principal applicants through the Skilled/Business stream in $2007 / 08$.

While the intake of nurses from the Philippines is not that high in terms of absolute numbers, it is important to note that their numbers have increased from 71 in 
$2003 / 04$ to around 115 in 2006/07. Nurses from India and South Africa make up a small and consistent proportion in the overall intake, however it is interesting to see that the number of registered nurses from China have significantly increased from 4 in 2003/04 to 66 in $2007 / 08$.

Table 1: Proportion of principal applicants coming into New Zealand through the Skilled/Business stream in independently and with secondary applicants, 2003/04-2007/08, All occupations, registered nurses \& doctors

\begin{tabular}{|c|c|c|c|c|}
\hline Principal applicants & & All occupations & Registered Nurses & Doctors $^{1}$ \\
\hline \multirow[t]{3}{*}{ female } & Independent & $47 \%$ & $33 \%$ & $52 \%$ \\
\hline & with 1 or more $\mathrm{SA}$ & $53 \%$ & $67 \%$ & $48 \%$ \\
\hline & total $(\mathrm{N})$ & 20,194 & 1,883 & 402 \\
\hline \multirow[t]{3}{*}{ male } & Independent & $33 \%$ & $33 \%$ & $31 \%$ \\
\hline & with 1 or more $\mathrm{SA}$ & $67 \%$ & $67 \%$ & $69 \%$ \\
\hline & total $(\mathrm{N})$ & 38,219 & 267 & 1089 \\
\hline
\end{tabular}

'Data period 2003/04 - 2006/07 from Callister et al 2008 (table 17)

Table 2: Proportion of registered nurses from top 5 nationalities coming into NZ through the Skilled/Business stream independently and with secondary applicants 2003/04 - 2007/08 (female only)

\begin{tabular}{|l|rrrrr|}
\hline & China & Great Britain & India & Philippines & South Africa \\
\hline Independent & $\mathbf{7 2 \%}$ & $25 \%$ & $24 \%$ & $39 \%$ & $11 \%$ \\
With 1 or more SA & $28 \%$ & $75 \%$ & $76 \%$ & $61 \%$ & $89 \%$ \\
\hline total $(\mathbb{N})$ & $\mathbf{1 2 0}$ & $\mathbf{7 6 1}$ & $\mathbf{1 8 6}$ & $\mathbf{3 7 0}$ & $\mathbf{1 0 6}$ \\
\hline
\end{tabular}

Table 1 examines the proportion of migrants who come into New Zealand independently and with one or more secondary applicant (as part of their residence application). Female principal applicants were just as likely to migrate independently and with 1 or more secondary applicant while their male counterparts were more like to migrate as a family unit than as solo migrants.

When specific occupational groups are examined, in this case registered nurses, female principal applicants were significantly more likely to migrate with 1 or more secondary applicant than independently (67 percent versus 33 percent). Although the numbers for male migrant nurses are small, they follow a similar pattern to that of female migrant nurses and that of all

\section{Temporary work permit analysis}

Table 3: Work permits issued to female migrants from the top 5 source countries

\begin{tabular}{|l|r|r|r|r|r|r|r|}
\hline & $\mathbf{2 0 0 3 / 0 4}$ & $\mathbf{2 0 0 4 / 0 5}$ & $\mathbf{2 0 0 5 / 0 6}$ & $\mathbf{2 0 0 6 / 0 7}$ & $\mathbf{2 0 0 7 / 0 8}$ & \% change & Total \\
\hline China & 3,265 & 5,972 & 10,201 & 13,301 & 13,202 & 304 & 45,941 \\
\hline Great Britain & 11,164 & 11,335 & 10,534 & 10,492 & 10,926 & -2 & 54,451 \\
\hline India & 1,966 & 2,303 & 2,514 & 2,858 & 3,542 & 80 & 13,183 \\
\hline Philippines & 723 & 842 & 1,445 & 2,529 & 4,294 & 494 & 9,833 \\
\hline South Africa & 1,935 & 2,039 & 2,054 & 2,545 & 3,221 & 66 & 11,794 \\
\hline
\end{tabular}

Table 4: Number of work permits issues to migrant nurses

\begin{tabular}{|l|r|r|r|r|r|r|}
\hline Gender & $\mathbf{2 0 0 3 / 0 4}$ & $\mathbf{2 0 0 4 / 0 5}$ & $\mathbf{2 0 0 5 / 0 6}$ & $\mathbf{2 0 0 6 / 0 7}$ & $\mathbf{2 0 0 7 / 0 8}$ & Total \\
\hline Female & 1401 & 1328 & 962 & 958 & 925 & 5574 \\
\hline Male & 232 & 190 & 153 & 174 & 219 & 968 \\
\hline total & 1633 & 1518 & 1115 & 1132 & 1144 & 6542 \\
\hline
\end{tabular}


Table 3 examines the number of temporary work permits issued to female migrants from 2003/04 to 2007/08 by nationality. Migrants from the Philippines have had the largest percent growth of $494 \%$ followed by migrants from China (304\%), while migrants from Great Britain have decreased by $2 \%$.

Table 4 shows that during 2003/04 and 2007/08 although the number of work permits issued to migrant nurses (both male and female) has declined, the numbers are still nearly double that of numbers migrating though the Skilled/Business stream, suggesting an increasing need in New Zealand for nurses. This growth is significant for migrant nurses China (17 in 2003/04 to 77 in 2007/08) as shown in Figure 3.

Similar to the Skilled/Business stream, Figure 3 also shows that nurses from Great Britain (although declining) form the largest supply followed by the Philippines. It is interesting to note that there are two times as many nurses from the Philippines on a work permit than those on a residence permit.

Figure 3: Temporary work permits issued to female migrants to work as nurses in New Zealand, 2003/04 2007/08

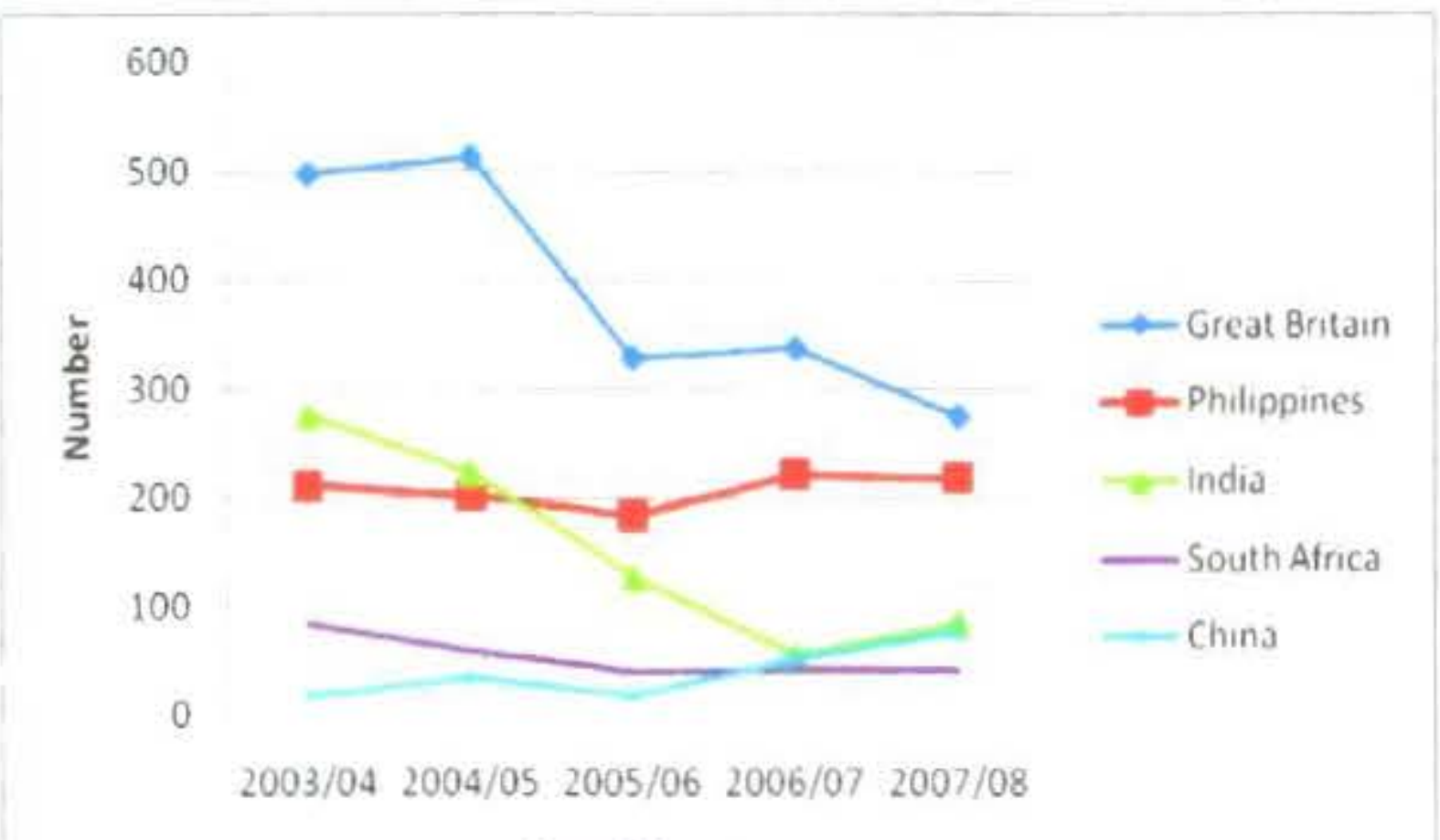

Financial year

\section{International nursing students}

While the peak of international students studying in New Zealand has past, overall since the late 1990 s there has been strong growth in the number of such students (Callister and Newell, 2008). At the end of their studies, international students are able to participate in the labour force because they can offer employers New Zealand qualifications (Merwood 2006). Ministry of Education data show that in 1995 there were just over 7,000 domestic nursing students enrolled in New Zealand. At this time there were just 50 international nursing students. By 2006, there were just over 9,600 domestic nursing students while the number of international students had risen to 760 . In 1995 international nursing students represented less than $1 \%$ of total enrolments, but this had risen to $7 \%$ by 2006 . Students from Asia have risen from around a third of international students, to two thirds by 2006. A significant proportion of the remaining international students reported Pacific ethnicities. $^{\text {? }}$

Table 5 shows that the proportion of New Zealand born women employed in the following occupational categories of Professional, Nursing \& Midwifery, Registered nurse and Doctors had decreased between the 1991 and 2006 census. Those born overseas had increased. For example, the proportion of people employed as Registered Nurses, who were born in New Zealand has decreased from 82 percent in 1991 to 72 percent in 2006, while those who were born overseas has increased from 18 percent in 1991 to 28 percent in 2006. Although the proportion of New Zealand born female doctors has decreased between 1991 and 2006, female nurses are still much more likely to be New Zealand born than female doctors.

Table 6 examines the age structure of women employed as Nursing and Midwifery professionals and as Registered nurses.

As the proportion of New Zealand born women employed as registered nurses has declined over the last 15 years, the proportion of overseas born women employed as registered nurses has doubled in the 15-24 (from 10 percent to 19 percent) and 25-34 (from 16 percent to 35 percent) year old groups between 1991 and 2006. The increase in the proportion of employed overseas born registered nurses in the 35 to 44 year old group is also evident (from 19 percent in 1991 to 33 percent in 2006). In the older age groups, (45-54; 55-64 and 65+ years), the proportion of employed overseas born nurses is relatively stable, however in 2001 , about a third of the registered nurses in the $65+$ age group were born overseas (decreasing to 24 percent in 2006 - which is consistent with the 1991 and 1996 censuses).

\section{Census data - female only}

Table 5: Proportion women employed in selected occupational ${ }^{1}$ groups by whether New Zealand born, census 1991 to 2006

\begin{tabular}{|l|r|r|r|r|}
\hline & Professionals & Nursing \& Midwifery & Registered nurse & Doctors \\
\hline 1991 & $81 \%$ & $81 \%$ & $82 \%$ & $59 \%$ \\
\hline 1996 & $80 \%$ & $81 \%$ & $82 \%$ & $58 \%$ \\
\hline 2001 & $77 \%$ & $77 \%$ & $78 \%$ & $54 \%$ \\
\hline 2006 & $73 \%$ & $72 \%$ & $72 \%$ & $48 \%$ \\
\hline
\end{tabular}

'Occupation (NZSCO99 v1.0) for employed usually resident population count aged 15 years and over. 
Table 6: Proportion women employed as Nursing \& Midwifery professionals and as Registered nurses ${ }^{1}$ by age group and whether New Zealand born, census 1991 to 2006

\begin{tabular}{|c|c|c|c|c|}
\hline & \multicolumn{4}{|c|}{ Nursing and Midwifery professionals } \\
\hline+1 & 1991 & 1996 & 2001 & 2006 \\
\hline $15-24$ & 90 & 91 & 88 & 81 \\
\hline $25-34$ & 83 & 82 & 75 & 66 \\
\hline $35-44$ & 81 & 81 & 77 & 67 \\
\hline $45-54$ & 78 & 78 & 78 & 75 \\
\hline $55-64$ & 75 & 75 & 77 & 77 \\
\hline \multirow[t]{3}{*}{$65+$} & 77 & 77 & 72 & 76 \\
\hline & \multicolumn{4}{|c|}{ Registered Nurses } \\
\hline & 1991 & 1996 & 2001 & 2006 \\
\hline $15-24$ & 90 & 91 & 88 & 81 \\
\hline $25-34$ & 84 & 83 & 75 & 65 \\
\hline $35-44$ & 81 & 82 & 77 & 67 \\
\hline $45-54$ & 78 & 79 & 79 & 75 \\
\hline $55-64$ & 75 & 77 & 78 & 78 \\
\hline $65+$ & 80 & 79 & 71 & 77 \\
\hline
\end{tabular}

'Occupation (NZSCO99 v1.0) for employed usually resident population count aged 15 and over.

Figure 4 looks at the proportion of women employed by age groups as registered nurses (aged care) by place of birth. Proportionately, overseas born nurses have a higher representation in the 35-44 year aged group than their New Zealand born counterparts ( 24 percent versus
14 percent respectively), while New Zealand born nurses have higher representation than their overseas born counterparts in the 55-64 year age group (30 percent versus 19 percent).

Figure 4: Proportion of women employed as Registered nurses (Aged care) by place of birth (New Zealand vs. Overseas) and age group, census $2006^{1}$

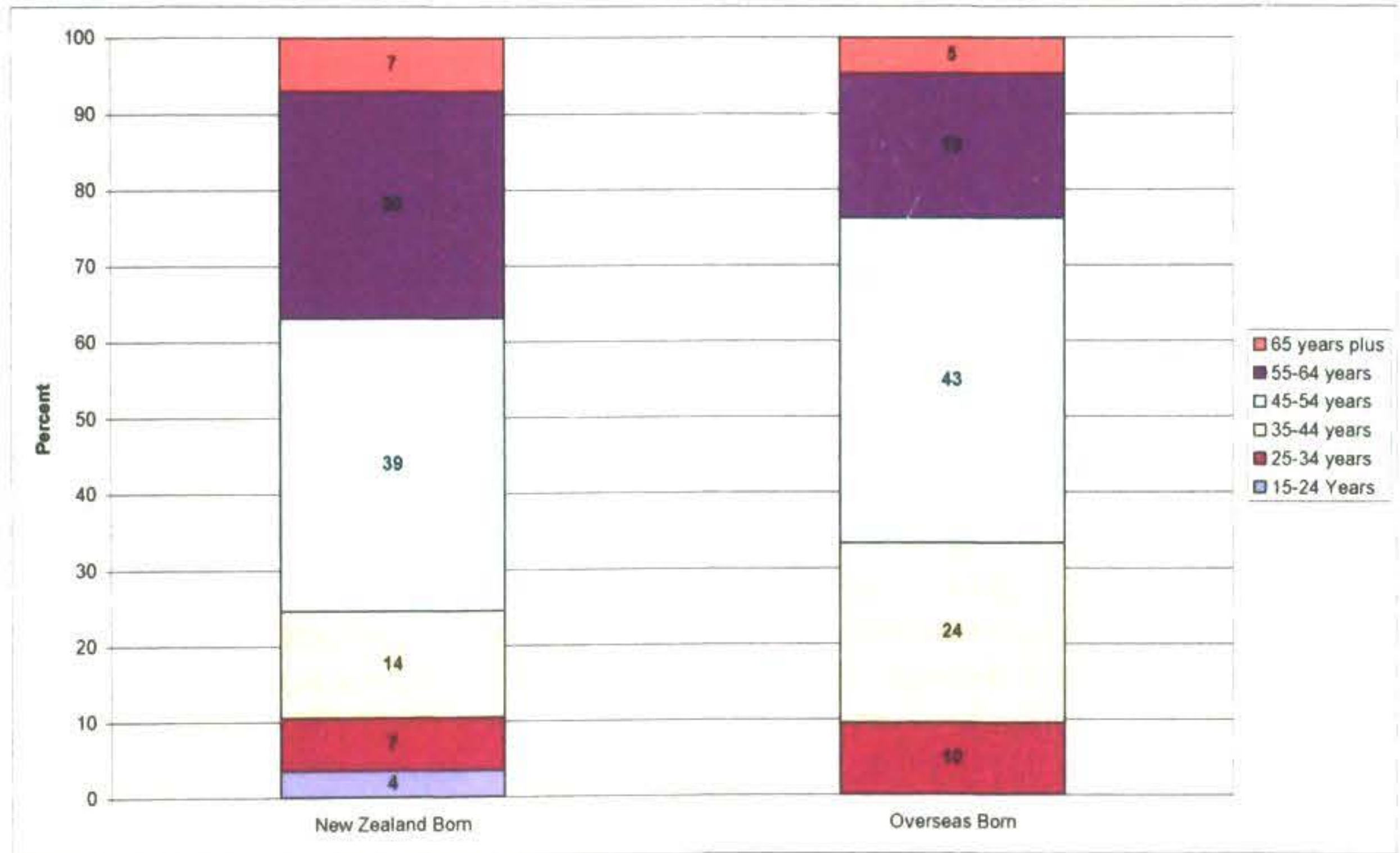

'Occupation (ANZSCO) for employed census usually resident population count aged 15 years and over

\section{Discussion}

The proportion of the New Zealand population born overseas has been increasing. In parallel, the source of migrants has been changing with a particular growth in migration from parts of Asia (Bromell, 2008). Skilled professionals, both those born in New Zealand and those born overseas, have become increasing mobile and this includes the rising number of skilled women who work in such professions. One result has been an increasing international migration of skilled women, both on their own or as part of family. Our recent research shows that health workers, including nurses and doctors, are part of these trends (Callister et al, 2008). 
As illustrated in this paper, severe staff and skill shortage within the health systems of developed countries such as New Zealand has led to the rise in migration of nurses, leading to significant changes in the proportion of nurses who were born in New Zealand and overseas. However it is important to note a limitation of this paper. Being born overseas does not necessarily imply that these nurses were trained overseas. Research shows that although born overseas, a significant proportion of health professionals in New Zealand and Australia were long term resident and had actually trained locally (Birrell and Dobson 2005; Callister et al 2008).

The migration of health professionals from developing to developed countries is expected to rise due decreased fertility and ageing populations in industrialised nations (Bach 2003).

Our study has shown that migrant nurses from parts of Asia, mainly the Philippines remain the primary source after the United Kingdom. The importance of gender flows in international skilled migration from the Asian region has been discussed previously (Badkar et al 2007). The current study also highlights the growth in migrant nurses from China. Although the numbers are small relative to other countries their absolute numbers have significantly increased. Although the number of foreign nursing students is relatively small it has been growing and this may be resulting in some Chinese students transitioning from student to work permits and then onto residence (Merwood 2007). The Free Trade Agreement with China, signed in 2008, might affect trends in nurse migration from China in the future (Hugo et al, 2008).

Our study also shows that while a third of female overseas-born nurses come as independent migrants, this is lower than overall female migrants and significantly lower than for female doctors. But this could be changing. The growth of nursing migrants from China comes with a pattern of over $70 \%$ of these nurses coming independently. Similar to our previous studies of gendered migration, and of doctors in particular, this study shows that there can be quite significant differences in how people are deciding to migrate to New Zealand. A better understanding of decision making both at an individual and at a family level would be useful.

The shift from a primarily New Zealand born to an increasingly diverse nursing workforce raises some challenges. In New Zealand, there is a concern about the relatively small numbers of Maori and Pacific nurses, although the numbers are increasing. Part of this concern is around issues of "cultural safety', or as the Nursing Council (2005) notes, 'the effective nursing practice of a person or family from another culture'. Our study also illustrates that a relatively large proportion of overseas born nurses aged between $35-44$ years are employed in the aged care sector. While we are not able to say what proportion are trained in New Zealand, it highlights the diversity of our nurses attending to our elderly population. A range of studies, including ours, suggest there is an increasing diversity of both clients and nurses in the health sector with the result that while we may be able to increase the delivery of services 'by Maori for Maori' or 'by Pacific for Pacific', we will also have more 'by Chinese for Maori' as well as many other complex cross-cultural nursing situations. Given that effective communication is so important in health delivery, there also remain some concern within the health sector about competency in English language amongst some migrants and there is on-going debate as to how to best overcome this problem. Yet, equally a more diverse nursing staff can help with communication with clients whose English language skills are limited (AUT, 2008).

Finally, this paper is a first part of a wider project designed to understand the changing health workforce. Next steps include analysing the changing composition of lower paid health care workers, particularly those caring for the increasing number of older people in New Zealand.

\section{Acknowledgements}

A number of funding sources assisted us in this research. We acknowledge the support from both the Department of Labour and Statistics New Zealand. Support came from both the Emerging Issues Fund and the Foundation for Research, Science and Technology. We would also like to thank Jamie Newell for supplying the Ministry of Education data used in this paper. However, the findings, opinions and conclusions expressed in this paper are strictly those of the authors.

\section{Notes}

1. 64 percent increase between $2003 / 04$ and 2005/06

2. In contrast New Zealand has the highest proportion of foreign-born doctors ( 47 percent).

3. Detailed information is available on www.immigration.govt.nz

4. In 2006/07 2,431 people from the Philippines were approved for residence through the Skilled/Business stream compared to 872 in 2005/06.

5. This was 16 percent more than in $2005 / 06$.

6. Immigration data does not capture Australian citizens.

7. We are examining the specific source countries of nursing students as part of our IPS working paper. 


\section{References}

Aiken, L. H., Buchan, J., Sochalski, J., Nichols, B., Powell,C. (2004). "Trends in international nurse migration." Health affairs 23(3): 69-77.

AUT (2008) NZ Diversity Forum 2008: Capitalising on a Diverse Health Workforce, http://www.aut.ac.nz/research/research_institutes/ niphmhr/centre_for_asian_and_migrant_health_r esearch/health_pra_forum.htm

Bach, S. (2003). International migration of health workers: labour and social issues. Geneva, International Labour Office.

Badkar, J., Callister, P. and Krishnan, V. (2006). Women, Skills and Global Mobility: A Study of Changing Patterns of Gendered Skilled Migration into New Zealand, paper presented at the 12th Labour, Employment and Work conference, Wellington: Victoria University.

Badkar, J. (2006). Life in New Zealand: Settlement Experiences of Skilled Migrants: Results from the 2005 Survey. Department of Labour, Wellington.

Badkar, J., Callister, P., Krishnan, V., Didham, R. and Bedford R. (2007). Gender, Mobility and Migration into New Zealand: A Case Study of Asian Migration. Social Policy Journal. Vol 32.

Birrell, B. and Hawthorne, L. (1996). "Immigrants and the professions." People and place 4(4 ): 1-11.

Birrell, B., and Dobson, I. (2005). Are Asians Overrepresented in training in the health professions? People and Place, vol 13, no. 4.

Boyd, C (2003). Migrants in New Zealand: An analysis of Labour Market Outcomes for Working Aged Migrants Using 1996 and 2001 Census Data. Department of Labour.

http://www.dol.govt.nz/publicationview.asp?ID $=140$

Bromell, D. (2008) Ethnicity, identity and public policy: Critical perspectives on multiculturalism. Wellington: Institute of Policy Studies.

Buchan, J. and Calman, L. (2004) The Global Shortage of Registered Nurses: An Overview of Issues and Actions, Geneva: International Council of Nurses.

Callister, P., Badkar, J. and Didham, R. "Who are New Zealand's doctors? Gender, migration and changing living arrangements." Institute of Policy Studies working paper May 2008.

Callister, P. and Newell, J. (2008) Gender and tertiary education enrolments and completions: An overview of trends 1994-2006, IPS Working
Paper 08/05, Wellington: Institute of Policy Studies.

Carling, J. (2005) Gender dimensions of international migration, background paper, Geneva: GCIM.

Cox, M. and Hope, S. (2006) Health service needs and labour force projections, in J.Boston and J. Davey (eds) Implications of population ageing: Opportunities and risks, Wellington, Institute of Policy Studies, pp 221-251.

Hawthorne, L. (1994). Labour market barriers for immigrant engineers in Australia. Canberra, Australian government publishing service.

Hawthorne, L. (1996). "Reversing past stereotypes: skilled NESB women in Australia." Jounrnal of intercultural studies 17(1-2): 41-52.

Hawthorne, L. (2001). "The globalisation of the nursing workforce: barriers confronting overseas qualified nurses in Australia." Nursing Inquiry 8(4): 213 229.

Hawthorne, L. (2002). "Qualifications recognition reform for skilled migrants in Australia: applying competency-based assessment to overseasqualified nurses." International migration 40(6): $55-91$.

Hawthorne, L. (2006). 'Picking Winners': Transforming employment outcomes in Australia's skill migration program. Department of Labour, New Zealand. Wellington.

Hawthorne, L. (2007). Labour market outcomes for migrant professionals: Canada and Australia compared, University of Melbourne.

Hugo, G., Callister, P. and Badkar, J. (2008) International labour mobility in Australia and New Zealand, Paper prepared for the PECC ABAC Conference on Demographic Change and International Labour Mobility in the Asia-Pacific Region: Implications for Business and Corporations, Seoul, South Korea, 25-26 March.

Merwood, P. (2008) "Migration Trends 2006/07." Department of Labour, Wellington.

Merwood, P. (2007) "International students: Studying and staying on in New Zealand." Department of Labour, Wellington.

Nursing Council of New Zealand (2005) Guidelines for Cultural Safety, the Treaty of Waitangi and Maori Health in Nursing Education and Practice, March http://www.nursingcouncil.org.nz/Cultural $\% 20 \mathrm{Sa}$ fety.pdf 
OECD (2007). Immigrant health workers in OECD countries in the broader context of highly skilled migration. International migration outlook: Sopemi 2007 edition, OECD 2007.

Winkelmann, Liliana and Winkelmann, Rainer (1998) Immigrants in the New Zealand Labour Market: A Study of their Labour Market Outcomes, New Zealand Department of Labour Occasional Paper 1998/1, June 1998.

Zurn, P. and J.C. Dumont (2008), "Health Workforce and International Migration: Can New Zealand Compete?" OECD Health Working Paper, No. 34, OECD, Paris.

\author{
Authors \\ Juthika Badkar \\ Research Fellow \\ Institute of Policy Studies \\ Victoria University of Wellington \\ P.O. Box 600 \\ Wellington 6140 \\ Juthika.Badkar@vuw.ac.nz \\ Paul Callister \\ Deputy Director \\ Institute of Policy Studies \\ Victoria University of Wellington \\ P.O. Box 600 \\ Wellington 6140 \\ Paul.Callister@vuw.ac.nz \\ Robert Didham \\ Statistics New Zealand \\ Statistics House \\ PO Box 2922 \\ Wellington 6140 \\ Robert.Didham@stats.govt.nz
}

